Research paper

\title{
Quantitative assessment of salivary oral bacteria according to the severity of dental caries in childhood
}

\author{
Natália H. Colombo ${ }^{a}$, Paula F. Kreling ${ }^{\mathrm{a}}$, Laís F.F. Ribas ${ }^{\mathrm{a}}$, Jesse A. Pereira ${ }^{\mathrm{a}}$, Christine A. Kressirer ${ }^{\mathrm{b}}$, \\ Marlise I. Klein ${ }^{\mathrm{d}}$, Anne C.R. Tanner ${ }^{\mathrm{b}, \mathrm{c}}$, Cristiane Duque ${ }^{\mathrm{a}, *}$ \\ ${ }^{a}$ São Paulo State University (UNESP), School of Dentistry, Araçatuba, Department of Pediatric Dentistry and Public Health, Araçatuba, SP, Brazil \\ b The Forsyth Institute, Department of Microbiology, Cambridge, MA, USA \\ c Harvard School of Dental Medicine, Harvard University, Boston, MA, USA \\ d São Paulo State University (UNESP), School of Dentistry, Araraquara, Department of Dental Materials and Prosthodontics, Araraquara, SP, Brazil
}

\section{A R T I C L E I N F O}

\section{Keywords:}

Early childhood caries

Quantitative polymerase chain reaction

Oral bacteria

\begin{abstract}
A B S T R A C T
This study aimed to assess differences in selected oral bacteria in children according to the severity of dental caries. One hundred and thirty-six children, 36-60 months old were divided into three groups according to caries status: caries-free (CF) ( $n=47)$, early childhood caries (ECC) $(n=40)$ and severe-early childhood caries (SECC) $(n=49)$. Saliva was collected for detection and quantification of selected oral streptococci, Actinomyces naeslundii, Lactobacillus spp., Bifidobacterium spp., and Scardovia wiggsiae by quantitative-polymerase chain reaction. The results showed that the detection and quantitative levels of $S$. mutans, $S$. sobrinus, Bifidobacterium spp. and $S$. wiggsiae were significantly higher in S-ECC children compared to CF and ECC children, while for $S$. salivarius were significantly higher in CF compared to ECC and S-ECC children. There was no statistical difference among the clinical groups for S. mitis, S. oralis, A. naeslundii and Lactobacillus spp. levels and detection. SECC children had a lower monthly family income, started tooth brushing later and were breastfeed for a longer duration compared to CF children. S. mutans levels were positively correlated with $S$. wiggsiae and Bifidobacterium spp. levels, lower mother's education and child bottle-feeding before sleeping and negatively correlated with $S$. salivarius. It was concluded that in addition to $S$. mutans, other bacterial species, including bifidobacteria, Scardovia wiggsiae and S. sobrinus, are associated with severity of early childhood caries, although their role in the progress of dental caries remains unclear.
\end{abstract}

\section{Introduction}

Dental caries remains the most common chronic infectious disease of childhood in both developed and developing countries (Colak, Dülgergil, Dalli, \& Hamidi, 2013; Vadiakas, 2008). In the USA, data from the National Health and Nutrition Examination Survey for 2011-2012 showed that approximately $23 \%$ of children aged $2-5$ years old had dental caries in primary teeth (Dye, Thronton-Evans, $\mathrm{Li}$, \& Iafolla, 2015). In Brazil, the prevalence was $48.2 \%$ for children under 5 years old children in 2010 (SB Brasil, 2010). According to American Academy of Pediatric Dentistry, early childhood caries (ECC) is defined as the presence of one or more decayed, missing teeth or filled tooth surfaces in any primary tooth in a child 71 months of age or younger. Further, in children 3 through 5 years of age, one or more cavitated, missing teeth (due to caries), or filled smooth surfaces in primary maxillary anterior teeth, or decayed, missing, or filled score of $\geq 4$ (age 3 ), $\geq 5$ (age 4), or $\geq 6$ (age 5 ) surfaces constitutes severe-early childhood caries (S-ECC). In children younger than 3 years of age, any sign of smooth-surface caries is indicative of S-ECC (American Academy of Pediatric Dentistry, 2014; Drury et al., 1999).

Severe forms of ECC can cause significant pain in children and are associated with a marked decrease in the quality of life and general health (Acs, Shulman, Ng, \& Chussid, 1999; Low, Tan, \& Schwartz, 1999). Untreated carious primary teeth can affect children physically and psychologically, influencing speech, nutrition, sleeping, as well as socialization, ability to learn and concentrate and a reduction of selfesteem (Colak et al., 2013). ECC can be associated with lower height and weight due to insufficient food consumption from eating discomfort with decayed teeth resulting in delayed physical development (Acs, Lodolini, Kaminsky, \& Cisneros, 1992).

The etiology of ECC is considered multifactorial because microbial, genetic, immunological, behavioral, environmental and socioeconomic

\footnotetext{
* Corresponding author at: São Paulo State University (UNESP), School of Dentistry, Araçatuba, Department of Pediatric Dentistry and Public Health, R. José Bonifácio, 1193, CEP: 16015-050, Araçatuba-SP, Brazil.

E-mail addresses: cristianeduque@yahoo.com.br, cduque@foa.unesp.br (C. Duque).
} 
factors contribute to risk of the occurrence and severity of the clinical disease (Selwitz, Ismail, \& Pitts, 2007). Although ECC is frequently associated with a poor diet and inadequate oral hygiene (Berkowitz, 2003; Davies, 1998), microorganisms are responsible for the biochemical changes, particularly acid production, on the tooth surface and consequently are essential for the development of this oral disease (Peterson, Snesrud, Schork, \& Bretz, 2011).

Streptococcus mutans is the bacterial species most frequently associated with dental caries. However, its presence is not enough to establish carious lesions in children (Loesche, 1986). Many other oral bacteria including Lactobacillus spp., non-mutans streptococci, Actinomyces spp. and Bifidobacterium spp. are also acidogenic and aciduric and are associated with caries (van Houte, Lopman, \& Kent, 1996). Streptococci and Actinomyces are the major initial colonizers of the tooth surface (Kolenbrander, 2000). Studies have shown that initial colonizers are involved in the etiology of dental caries. Higher levels of $S$. mitis and $S$. oralis have been observed in caries active children than in cariesfree children (Becker et al., 2002). Furthermore, high prevalence of $S$. salivarius was found in carious lesions and biofilms of caries active children (Kouidhi et al., 2014). Research focused on the microbiota of severe-early childhood caries has shown that besides $S$. mutans (Kanasi, Dewhirst et al., 2010; Tanner, Kent et al., 2011), other bacteria such as Streptococcus sobrinus (Palmer et al., 2010), Bifidobacteriaceae (Palmer et al., 2010; Tanner, Kent et al., 2011), and a new species, Scardovia wiggsiae (Tanner, Kent et al., 2011; Tanner, Mathney et al., 2011) are associated with severe-ECC.

To our knowledge, no studies have compared the bacteria newly associated with severe-early childhood caries in children with lower degrees of caries severity. This study aimed to identify and quantify differences in salivary oral microbiota among caries-free, ECC and severe-ECC children to evaluate whether the species associations with caries occur in additional populations and if the species associated with S-ECC are also associated with less advanced caries.

\section{Methods}

\subsection{Samples size calculation}

The samples size calculation was performed based in the results obtained by Tanner, Kent et al. (2011), Tanner, Mathney et al. (2011) considering the major species associated with severe-early childhood caries: Streptococcus mutans and Scardovia wiggsiae. The authors detected a difference of 0.36 and 0.32 between proportions of caries-free and caries-affected children presenting $S$. mutans and $S$. wiggsiae, respectively. In order to detect such a difference at a significance level of $5 \%$ and a statistical power of 0.80 , a minimum of 34 children in each group were required and the total size needed was 120 children. The samples size was calculated using the chi-square test on proportion, by the website http://www.biomath.info/.

\subsection{Subjects recruitment and oral examination}

The study population included children who attended the four public nursery schools in the city of Araçatuba, São Paulo, Brazil. The city's population has access to a public water supply that contains fluoride levels of $0.7 \mathrm{ppm}$. The children's parents granted written permission, and the preschoolers assented verbally for the study, which had been previously approved by the Research Ethics Committee of Univ. Estadual Paulista (UNESP), Brazil (Certificate of Presentation for Ethical Consideration (CAAE) \#13079213.4.0000.5420).

Clinical examinations were carried out at the nursery schools by a single trained and calibrated examiner (NHC) using mouth mirrors illuminated by an intraoral light-emitting diode (LED) light. The criterion for inclusion in the study was children of both genders with complete deciduous dentition. Caries was scored by tooth surface as decayed, missing and filled (dmfs) surfaces. Children suffering from systemic diseases, or using long-term medications or antibiotics less than one month before the examination and children with mucosal lesions or those who refused to cooperate in dental examination or saliva collection were excluded from the study. Children with only restored or missing teeth or have only white spots without the presence of cavitated lesions were also excluded.

One hundred and thirty-six children from both genders, 36-60 months of age were included in this study. Children were divided into three groups according to oral health status: caries-free group (CF) ( $n=47$ ), early childhood caries group (ECC) $(n=40)$ and severe-early childhood caries group (S-ECC) $(n=49)$. In the CF group, only children with all sound teeth $(\mathrm{dmfs}=0)$ were included, ECC was defined for this study as the presence of 1 to 3 decayed tooth surfaces (cavitated lesions) in primary teeth, S-ECC was defined as the presence of a decayed surface score of $\geq 4$ (age 3 years), $\geq 5$ (age 4 years), $\geq 6$ (age 5 years) (American Academy of Pediatric Dentistry, 2014; Drury et al., 1999) with at least one smooth-surface carious lesion. Radiographs were not used as part of the routine, but if interproximal caries was suspected, patients were referred to the pediatric dental clinic at the School of Dentistry and had bitewing radiographs taken by the same initial examiner (NHC). Other suspected forms of oral pathologies were also investigated by using radiographs or more precise examination methods if necessary. All children with dental needs were offered treatment or referred for treatment.

\subsection{Questionnaire survey and dietary sugar evaluation}

The children's parents completed questionnaires to assess socioeconomic, cultural and oral hygiene habits. Dietary data was obtained from a food-frequency diary filled out for three consecutive days. This diary included the time of the day that the children ate and drank anything as well as the content of all meals and snacks. The amount of sugar exposure (liquid, solid and total sugar) was determined from the mean (standard deviation) of meals containing sugar a day, measured over a three-day period. In addition, the daily frequency of baby bottle consumption was also recorded.

\subsection{Saliva collection}

Unstimulated whole saliva was collected from each subject by direct expectoration into $50 \mathrm{~mL}$ sterile falcon conical tubes for 5-10 min. Collections were performed at least $1 \mathrm{~h}$ after food intake to avoid contamination with non-salivary components. Tubes were transported on ice to the laboratory and processed within $1 \mathrm{~h}$. The saliva was clarified by centrifugation at $10,000 \mathrm{rpm}$ at $4{ }^{\circ} \mathrm{C}$ for $10 \mathrm{~min}$. The supernatant was stored at $-70{ }^{\circ} \mathrm{C}$ for future analysis and the resulting pellet was used for DNA extraction and qPCR microbial analysis.

\subsection{DNA extraction}

DNA was extracted using a protocol previously described (Sardi, Duque, Camargo, Hofling, \& Gonçalves, 2011). Briefly, samples were lysed with extraction buffer and treated with proteinase K (Sigma-Aldrich, St. Louis, MO, USA) They were then purified using chloroform and isoamyl alcohol, followed by DNA precipitation with isopropanol and washing with $70 \%$ ethanol. The DNA was re-suspended in TE buffer (10 mM Tris-HCl, $0.1 \mathrm{mM}$ EDTA, pH 7.5), with $10 \mu \mathrm{g} / \mathrm{mL}$ RNAse and stored at $-20{ }^{\circ} \mathrm{C}$ for $\mathrm{qPCR}$ analysis.

\subsection{Quantitative-PCR analysis}

DNA concentration and quality were analyzed using a Nanodrop 8000 Spectrophotometer (Thermo Fisher Scientific, Wilmington, DE, USA) at $260 \mathrm{~nm}$. For samples less than $12.5 \mathrm{ng} / \mu \mathrm{l}$, DNA was amplified using Ready-to-go GenomiPhi V3 DNA Amplification Kit (GE Healthcare, Piscataway, NJ, USA). Samples were analyzed for detection 
Table 1

Primers used in qPCR analysis.

\begin{tabular}{|c|c|c|c|c|}
\hline Species & Primer & Primer sequence $\left(5^{\prime}-3^{\prime}\right)$ & Amplicon size (bp) & References \\
\hline A. naeslundii & $\begin{array}{l}\text { Forward } \\
\text { Reverse }\end{array}$ & $\begin{array}{l}\text { CCTCTGGCTTAACTGGGG } \\
\text { CATTCCACCGCTACACCA }\end{array}$ & 88 & Xiao et al. (2012) \\
\hline Bifidobacterium spp. & $\begin{array}{l}\text { Forward } \\
\text { Reverse }\end{array}$ & $\begin{array}{l}\text { CTCCTGGAAACGGGTGG } \\
\text { GGTGTTCTTCCCGATATCTACA }\end{array}$ & $549-563$ & Matsuki et al. (2004) \\
\hline Lactobacillus spp. & $\begin{array}{l}\text { Forward } \\
\text { Reverse }\end{array}$ & $\begin{array}{l}\text { TGGAAACAGRTGCTAATACCG } \\
\text { GTCCATTGTGGAAGATTCCC }\end{array}$ & $231-233$ & Byun et al. (2004) \\
\hline S. mitis & $\begin{array}{l}\text { Forward } \\
\text { Reverse }\end{array}$ & $\begin{array}{l}\text { AGTTACAAACCCATACGCTG } \\
\text { ACTCAACATCACCTGCTGC }\end{array}$ & 230 & - \\
\hline S. mutans & $\begin{array}{l}\text { Forward } \\
\text { Reverse }\end{array}$ & $\begin{array}{l}\text { CTACACTTTCGGGTGGCTTG } \\
\text { GAAGCTTTTCACCATTAGAAGCTG }\end{array}$ & 261 & Choi et al. (2009) \\
\hline S. oralis & $\begin{array}{l}\text { Forward } \\
\text { Reverse }\end{array}$ & $\begin{array}{l}\text { GCTTTGACCGAACAGTTTCC } \\
\text { CATTGGTATTCCCCACCTTG }\end{array}$ & 457 & Park et al. (2010) \\
\hline S. salivarius & $\begin{array}{l}\text { Forward } \\
\text { Reverse }\end{array}$ & $\begin{array}{l}\text { CACGCTCACAATACATCGG } \\
\text { CAACACCATCGCCTTCAAT }\end{array}$ & 157 & - \\
\hline S. sobrinus & $\begin{array}{l}\text { Forward } \\
\text { Reverse }\end{array}$ & $\begin{array}{l}\text { AAAACATTGGGTTACGATTGCG } \\
\text { CGTCATTGGTAGTAGCCTGA }\end{array}$ & 156 & Choi et al. (2009) \\
\hline Scardovia wiggsiae & $\begin{array}{l}\text { Forward } \\
\text { Reverse }\end{array}$ & $\begin{array}{l}\text { GTGGACTTTATGAATAAGC } \\
\text { CTACCGTTAAGCAGTAAG }\end{array}$ & 200 & Tanner, Kent et al., 2011 (2011) \\
\hline
\end{tabular}

Table 2

Thermal conditions applied for qPCR analysis.

\begin{tabular}{|c|c|c|c|c|c|}
\hline \multirow[t]{2}{*}{ Species } & \multicolumn{5}{|c|}{ Thermal conditions } \\
\hline & pre-heating & denaturation & annealing & elongation & cycles \\
\hline A. naeslundii & $95^{\circ} \mathrm{C}, 3 \mathrm{~min}$ & $94^{\circ} \mathrm{C}, 15 \mathrm{~s}$ & $58^{\circ} \mathrm{C}, 30 \mathrm{~s}$ & $68^{\circ} \mathrm{C}, 15 \mathrm{~s}$ & 35 \\
\hline Bifidobacterium spp. & $95^{\circ} \mathrm{C}, 10 \mathrm{~min}$ & $95^{\circ} \mathrm{C}, 20 \mathrm{~s}$ & $55^{\circ} \mathrm{C}, 20 \mathrm{~s}$ & $72^{\circ} \mathrm{C}, 50 \mathrm{~s}$ & 40 \\
\hline Lactobacillus spp. & $95^{\circ} \mathrm{C}, 10 \mathrm{~min}$ & $95^{\circ} \mathrm{C}, 15 \mathrm{~s}$ & $59^{\circ} \mathrm{C}, 20 \mathrm{~s}$ & $72{ }^{\circ} \mathrm{C}, 30 \mathrm{~s}$ & 40 \\
\hline S. mitis & $95^{\circ} \mathrm{C}, 3 \mathrm{~min}$ & $94^{\circ} \mathrm{C}, 15 \mathrm{~s}$ & $54^{\circ} \mathrm{C}, 15 \mathrm{~s}$ & $72{ }^{\circ} \mathrm{C}, 30 \mathrm{~s}$ & 40 \\
\hline S. mutans & $94^{\circ} \mathrm{C}, 7 \mathrm{~min}$ & $94^{\circ} \mathrm{C}, 20 \mathrm{~s}$ & $56^{\circ} \mathrm{C}, 20 \mathrm{~s}$ & $72{ }^{\circ} \mathrm{C}, 33 \mathrm{~s}$ & 40 \\
\hline S. oralis & $94^{\circ} \mathrm{C}, 5 \mathrm{~min}$ & $94^{\circ} \mathrm{C}, 30 \mathrm{~s}$ & $58^{\circ} \mathrm{C}, 40 \mathrm{~s}$ & $72{ }^{\circ} \mathrm{C}, 40 \mathrm{~s}$ & 40 \\
\hline S. salivarius & $94^{\circ} \mathrm{C}, 5 \mathrm{~min}$ & $94^{\circ} \mathrm{C}, 30 \mathrm{~s}$ & $58^{\circ} \mathrm{C}, 40 \mathrm{~s}$ & $72^{\circ} \mathrm{C}, 40 \mathrm{~s}$ & 40 \\
\hline S. sobrinus & $94^{\circ} \mathrm{C}, 7 \mathrm{~min}$ & $94^{\circ} \mathrm{C}, 20 \mathrm{~s}$ & $58^{\circ} \mathrm{C}, 20 \mathrm{~s}$ & $72{ }^{\circ} \mathrm{C}, 33 \mathrm{~s}$ & 40 \\
\hline Scardovia wiggsiae & $94^{\circ} \mathrm{C}, 2 \mathrm{~min}$ & $94^{\circ} \mathrm{C}, 20 \mathrm{~s}$ & $51^{\circ} \mathrm{C}, 20 \mathrm{~s}$ & $72{ }^{\circ} \mathrm{C}, 20 \mathrm{~s}$ & 40 \\
\hline
\end{tabular}

and quantification of: S. mitis, S. oralis (Park, Lee, Jeong, Shin, \& Kim, 2010), S. salivarius, S. mutans (Choi, Lee, \& Kim, 2009), S. sobrinus (Choi et al., 2009), Lactobacillus spp. (Byun et al., 2004), Actinomyces naeslundii (Xiao et al., 2012), Bifidobacterium spp. (Matsuki et al., 2004) and Scardovia wiggsiae (Tanner, Kent et al., 2011) using a Roche Lightcycler 480 (Roche, USA) for quantitative PCR (qPCR). Table 1 shows the primers sequences and amplicons sizes for each bacterial species evaluated in this study. The amplification programs corresponding to the published primer protocols and two new primers, designed in PRIMER3 program (http://bioinfo.ut.ee/primer3-0.4.0/), analyzed in NETPRIMER (http://www.premierbiosoft.com/netprimer/ ) and BLASTn (https://blast.ncbi.nlm.nih.gov/Blast.cgi?PAGE_TYPE = BlastSearch) and tested against several oral bacterial species (data not shown), are showed in Table 2. The reaction mixture $(20 \mu \mathrm{L})$ was composed of $10 \mu \mathrm{L}$ of SYBR Green qPCR Master (Roche), $2 \mu \mathrm{L}$ of each specific primer $(20 \mu \mathrm{M}), 4 \mu \mathrm{L}$ of diluted template DNA and $4 \mu \mathrm{L}$ of deionized water. The quantity of DNA was calculated from standard curves for each bacterial species, using DNA controls from standard bacterial cultures, which ranged from 0.001 to $100 \mathrm{ng} / \mathrm{mL}$. After the final cycle of qPCR, analysis of the cycle threshold (CT) and melting temperature $(\mathrm{Tm})$ values were carried out in all the amplified samples. Samples were considered negative for bacterial species when their CT and $\mathrm{Tm}$ values were below the level of detection in the curves of DNA standards.

\subsection{Statistical analysis}

The statistical analysis was performed using SPSS software version 18.0 (SPSS Inc. Chicago, USA), considering the three groups of children according to caries status (CF, ECC and S-ECC) as the dependent variables. The Kolmogorov-Smirnov test was used to verify the distribution of the data. ANOVA and Tukey tests were applied for quantitative data and Kruskal-Wallis and Dunn's tests for qualitative data from questionnaires and dietary evaluation. Mann-Whitey $U$ tests were applied to compare data from detection and quantification of microorganisms between CF x ECC, ECC x S-ECC and CF x S-ECC groups. Spearman's rho correlations were used to compare levels of bacteria and socio-economic cultural aspects, hygiene and dietary habits. For all analyses, a level of significance of $5 \%$ was considered.

\section{Results}

\subsection{Description of study populations}

A total of 150 children were invited to enroll in the present study50 children per group - following the samples size calculation of a minimum of 34 children per group. However, 9.33\% dropped out mainly because of difficulties in collecting sufficient saliva for microbiological analyses, leaving a population of 136 participants. Data from $\mathrm{dmfs}$ caries scoring, age, gender, socio-economic, cultural and oral hygiene and dietary habits are in Table 3 . The average age of the population was $48.70 \pm 8.94$ months of age and $55.46 \%$ were girls. The 
Table 3

Comparative analysis between the severity of early childhood caries and related etiological factors.

\begin{tabular}{|c|c|c|c|c|}
\hline & $\mathrm{CF} n=47$ & $\mathrm{ECC} n=40$ & S-ECC $n=49$ & $p$ value \\
\hline \multicolumn{5}{|l|}{ Characteristics of populations } \\
\hline $\operatorname{dmfs}($ mean $\pm \mathrm{SD})$ & 0 & $2.28 \pm 1.36$ & $18.02 \pm 15.62$ & 0.000 \\
\hline Age in months (mean $\pm \mathrm{SD}$ ) & $48.16 \pm 7.99$ & $48.43 \pm 9.10$ & $49.53 \pm 9.75$ & 0.735 \\
\hline Gender (\%) Female & 55.6 & 47.5 & 63.3 & 0.331 \\
\hline \multicolumn{5}{|l|}{ Socio-economic, cultural and oral hygiene habits } \\
\hline Children with reduced family income/month $(\%)^{\mathrm{a}}$ & 35.6 & 45 & 63.3 & 0.024 \\
\hline Number of children per family (mean $\pm \mathrm{SD}$ ) & $1.91 \pm 0.79$ & $2.16 \pm 1.21$ & $2.13 \pm 1.08$ & 0.546 \\
\hline Mother's education - up to 8 years $(\%)^{\mathrm{b}}$ & 31.1 & 30 & 44.9 & 0.252 \\
\hline Tooth brushing started with tooth eruption (\%) & 65.1 & 42.9 & 48.6 & 0.026 \\
\hline Frequency of tooth brushing/per day (mean \pm SD) & $2.42 \pm 0.80$ & $2.44 \pm 0.94$ & $2.14 \pm 0.97$ & 0.247 \\
\hline Adult's help with tooth brushing (\%) & 77.8 & 65 & 63.3 & 0.268 \\
\hline \multicolumn{5}{|l|}{ Dietary habits } \\
\hline Liquid sugar exposure/day (mean $\pm \mathrm{SD})^{\mathrm{c}}$ & $4.38 \pm 1.35$ & $5.02 \pm 2.75$ & $4.53 \pm 1.52$ & 0.438 \\
\hline Solid sugar exposure/day (mean $\pm \mathrm{SD})^{\mathrm{c}}$ & $3.33 \pm 1.26$ & $3.56 \pm 1.94$ & $2.99 \pm 1.48$ & 0.298 \\
\hline Total sugar exposure/day (mean $\pm \mathrm{SD})^{\mathrm{c}}$ & $7.61 \pm 2.09$ & $8.34 \pm 3.58$ & $7.49 \pm 2.17$ & 0.282 \\
\hline Breastfeeding $(\%)^{\mathrm{d}}$ & 81 & 85.7 & 93.6 & 0.085 \\
\hline Duration of breastfeeding - in months (mean $\pm \mathrm{SD}$ ) & $7.38 \pm 7.5$ & $15.88 \pm 14.84$ & $15.80 \pm 11.43$ & 0.001 \\
\hline Bottle-feeding $(\%)^{\mathrm{d}}$ & 88.9 & 75 & 81.6 & 0.251 \\
\hline Duration of bottle-feeding - in months (mean $\pm \mathrm{SD}$ ) & $33.43 \pm 17.69$ & $28.80 \pm 18.34$ & $30.97 \pm 16.57$ & 0.571 \\
\hline Bottle/breast feeding before sleeping (\%) & 75.6 & 75 & 83.3 & 0.608 \\
\hline
\end{tabular}

$\mathrm{p}<0.05$

Notes: The chi-square test was used for statistical analysis, comparing CFxECC, ECCxS-ECC and CFxS-ECC.

CF - caries-free, ECC - early childhood caries, S-ECC - severe-early childhood caries.

${ }^{a}$ Percentage of children whose parents earning less than R\$ 1448.00 per month (R\$ - Brazilian real. 1 US\$ R R 3.20 (2016, May).

${ }^{\mathrm{b}}$ Percentage of children whose mothers had up to 8 years of education.

${ }^{c}$ Mean (SD) of meals containing sugar per day, considering three days of evaluation for each children.

${ }^{\mathrm{d}}$ Percentage of children who were breastfed or artificially fed by baby bottle (bottle-feeding), regardless of whether this habit was discontinued or not.

S-ECC children came from families with a lower monthly income, started tooth brushing later and were breastfeed for a longer duration compared to CF children. Mothers of children with S-ECC had a lower education level than ECC and CF, but the differences were not statistically significant. Sugar intake, independent on the form (liquid, solid or both) did not differ among the groups.

When determining the correlations between salivary bacterial levels and socio-economic/cultural aspects, hygiene and dietary habits, results in Table 4 show that $S$. mutans levels were significantly positive correlated with lower mother's education and child bottle-feeding before sleeping. For $S$. sobrinus, a negative correlation was observed for adult's help with tooth brushing. Positive correlation between $S$. wiggsiae or Bifidobacterium spp. and the frequency of breastfeeding was observed. S. salivarius was negatively correlated with the frequency of breastfeeding (Table 4).

\subsection{Detection of bacterial species}

The percentage of children harboring the bacterial species evaluated is in Fig. 1. The detection of S. mutans, S. sobrinus, Bifidobacterium spp. and $S$. wiggsiae increased significantly with caries severity, while the detection of $S$. salivarius increased in CF children and was similar between ECC and S-ECC. There was no statistical difference among the groups of children for the detection of $S$. mitis, $S$. oralis, A. naeslundii and Lactobacillus spp.

\subsection{Quantification of bacteria}

The quantitative results of qPCR for each bacteria species, according to caries status, are in Table 5. The levels of $S$. sobrinus, Bifidobacterium spp. and S. wiggsiae were significantly higher in S-ECC children compared to CF and ECC children, however, there was no statistical difference between ECC and CF children. $S$. mutans levels increased with caries severity. In contrast, levels $S$. salivarius were significantly higher in CF compared to ECC and S-ECC children. There was no statistical difference among the groups for $S$. mitis, $S$. oralis, A. naeslundii or
Lactobacillus spp. levels.

There was a positive correlation among the bacterial species evaluated in this study. Levels of $S$. mutans were positively correlated with $S$. wiggsiae, Bifidobacterium spp. and negatively correlated with $S$. salivarius. Besides $S$. mutans, Bifidobacterium spp. was positively correlated with $S$. sobrinus and $S$. wiggsiae and negatively correlated with $S$. salivarius (Table 5).

\section{Discussion}

This study showed increased levels of Bifidobacterium spp. and Scardovia wiggsiae in saliva of children with ECC and S-ECC. Although the percentage of children harboring Bifidobacterium spp. and $S$. wiggsiae increased with caries severity, levels were higher only in S-ECC compared to CF and ECC children, but not between CF and ECC children. These differences between the microbiota of CF compared to SECC children are consistent with previous reports in the literature (Tanner, Kent et al., 2011; Tanner, Mathney et al., 2011; Zhou, Qin, Qin, \& Ge, 2011).

Species of Bifidobacterium have been associated with the progression of dental caries (Becker et al., 2002; Tanner, Mathney et al., 2011). One study reported that Bifidobacterium spp. were the most frequently bacterial species identified in carious dentin, more than $S$. mutans (Becker et al., 2002). The same study reported that the levels of Lactobacillus fermentum were lower when compared to those detected for Bifidobacterium species in carious dentin. These authors suggested that the major secondary pathogens in S-ECC are not Lactobacillus spp. but rather Bifidobacterium spp. (Becker et al., 2002). Species in Scardovia, a genus in the Bifidobacterium family, have been identified in cavitated dentin lesions in addition to Streptococcus and Lactobacillus (Jiang et al., 2014). Studies using culture (Tanner, Mathney et al., 2011) and PCR methods (Tanner et al., 2011a) have reported the association of Scardovia wiggsiae with S-ECC. However, these studies did not report bacterial levels. In the present study, $S$. wiggsiae was positively correlated with $S$. mutans.

Although other bacteria have been highlighted in ECC etiology, $S$. 
Table 4

Relationship between salivary levels of bacteria and socio-economic/cultural aspects, hygiene and dietary habits.

\begin{tabular}{|c|c|c|c|c|c|}
\hline & S. mutans & S. sobrinus & S. wiggsiae & Bifidobacterium spp. & S. salivarius \\
\hline \multicolumn{6}{|c|}{ Socio-economic cultural aspects } \\
\hline \multirow[t]{2}{*}{ dmfs } & 0.515 & 0.340 & $0.374^{*}$ & $0.608^{*}$ & $-0.276^{*}$ \\
\hline & $(0.000)$ & $(0.000)$ & $(0.000)$ & $(0.000)$ & $(0.006)$ \\
\hline \multirow[t]{2}{*}{ Age } & 0.043 & 0.076 & 0.135 & 0.168 & 0.142 \\
\hline & $(0.637)$ & $(0.384)$ & $(0.120)$ & $(0.053)$ & $(0.162)$ \\
\hline \multirow[t]{2}{*}{ Reduced Family income } & -0.004 & -0.155 & -0.123 & -0.134 & -0.169 \\
\hline & $(0.965)$ & $(0.074)$ & $(0.158)$ & $(0.123)$ & $(0.096)$ \\
\hline \multirow[t]{2}{*}{ Number of children/family } & -0.022 & -0.047 & -0.071 & -0.048 & 0.059 \\
\hline & $(0.823)$ & $(0.622)$ & $(0.460)$ & $(0.612)$ & $(0.585)$ \\
\hline \multirow[t]{3}{*}{ Mother's education } & 0.226 & -0.002 & 0.086 & 0.126 & 0.012 \\
\hline & $(0.011)$ & $(0.983)$ & $(0.324)$ & $(0.146)$ & $(0.903)$ \\
\hline & & Hygiene $h$ & & & \\
\hline \multirow[t]{2}{*}{ Frequency of toothbrushing } & -0.086 & 0.099 & -0.138 & -0.053 & -0.174 \\
\hline & $(0.374)$ & $(0.284)$ & $(0.135)$ & $(0.571)$ & $(0.115)$ \\
\hline \multirow[t]{2}{*}{ Tooth brushing started with tooth eruption } & 0.029 & -0.043 & 0.090 & 0.106 & -0.026 \\
\hline & $(0.783)$ & $(0.664)$ & $(0.363)$ & $(0.284)$ & $(0.833)$ \\
\hline \multirow[t]{2}{*}{ Adult's help with toothbrushing } & -0.026 & -0.240 & -0.082 & -0.094 & -0.183 \\
\hline & $(0.778)$ & $(0.005)$ & $(0.346)$ & $(0.279)$ & $(0.071)$ \\
\hline \multicolumn{6}{|c|}{ Dietary habits } \\
\hline \multirow[t]{2}{*}{ Liquid sugar exposure/day } & 0.099 & 0.038 & 0.066 & 0.079 & 0.010 \\
\hline & $(0.270)$ & $(0.660)$ & $(0.450)$ & $(0.364)$ & $(0.919)$ \\
\hline \multirow[t]{2}{*}{ Solid sugar exposure/day } & 0.134 & 0.162 & -0.018 & 0.019 & -0.023 \\
\hline & $(0.135)$ & $(0.062)$ & $(0.840)$ & $(0.828)$ & $(0.824)$ \\
\hline \multirow[t]{2}{*}{ Total sugar exposure/day } & 0.165 & 0.117 & 0.042 & 0.093 & -0.011 \\
\hline & $(0.066)$ & $(0.178)$ & $(0.628)$ & $(0.288)$ & $(0.983)$ \\
\hline \multirow[t]{2}{*}{ Breastfeeding } & 0.083 & 0.041 & 0.100 & $0.208^{*}$ & -0.222 \\
\hline & $(0.381)$ & $(0.654)$ & $(0.271)$ & $(0.021)$ & $(0.038)$ \\
\hline \multirow[t]{2}{*}{ Duration of Breastfeeding } & 0.158 & 0.079 & 0.258 & $0.237^{*}$ & -0.234 \\
\hline & $(0.092)$ & $(0.382)$ & $(0.004)$ & $(0.008)$ & $(0.028)$ \\
\hline \multirow[t]{2}{*}{ Bottle-feeding } & $0.259^{*}$ & 0.037 & -0.016 & 0.151 & -0.057 \\
\hline & $(0.004)$ & $(0.672)$ & $(0.852)$ & $(0.081)$ & $(0.577)$ \\
\hline \multirow[t]{2}{*}{ Duration of bottle-feeding } & -0.057 & 0.014 & -0.117 & -0.041 & 0.112 \\
\hline & $(0.586)$ & $(0.892)$ & $(0.239)$ & $(0.683)$ & $(0.335)$ \\
\hline \multirow[t]{2}{*}{ Bottle-feeding before sleeping } & 0.254 & 0.113 & -0.025 & 0.032 & -0.078 \\
\hline & $(0.009)$ & $(0.231)$ & $(0.794)$ & $(0.738)$ & $(0.487)$ \\
\hline \multicolumn{6}{|c|}{ Microbiota } \\
\hline \multirow[t]{2}{*}{ S. mutans } & - & 0.169 & $0.303^{*}$ & $0.607^{*}$ & $-0.350^{*}$ \\
\hline & & $(0.060)$ & $(0.001)$ & $(0.000)$ & $(0.001)$ \\
\hline \multirow[t]{2}{*}{ S. sobrinus } & 0.169 & - & 0.136 & 0.336 & -0.099 \\
\hline & $(0.060)$ & & $(0.118)$ & $(0.000)$ & $(0.332)$ \\
\hline \multirow[t]{2}{*}{ S. wiggisiae } & $0.303^{k}$ & 0.136 & - & $0.643^{*}$ & -0.103 \\
\hline & $(0.001)$ & $(0.118)$ & & $(0.000)$ & $(0.315)$ \\
\hline \multirow[t]{2}{*}{ Bifidobacterium spp. } & $0.607^{*}$ & $0.336^{*}$ & $0.643^{*}$ & - & -0.198 \\
\hline & $(0.000)$ & $(0.000)$ & $(0.000)$ & & $(0.050)$ \\
\hline S. salivarius & -0.350 & -0.099 & -0.103 & $-0.198^{*}$ & - \\
\hline & $(0.001)$ & $(0.332)$ & $(0.315)$ & $(0.050)$ & \\
\hline
\end{tabular}

$\mathrm{p}<0.05$

* Correlation coefficient ( $p$ value) obtained after comparison of bivariate data using Spearman's rho Correlation test, at a level of significant of 5\%.

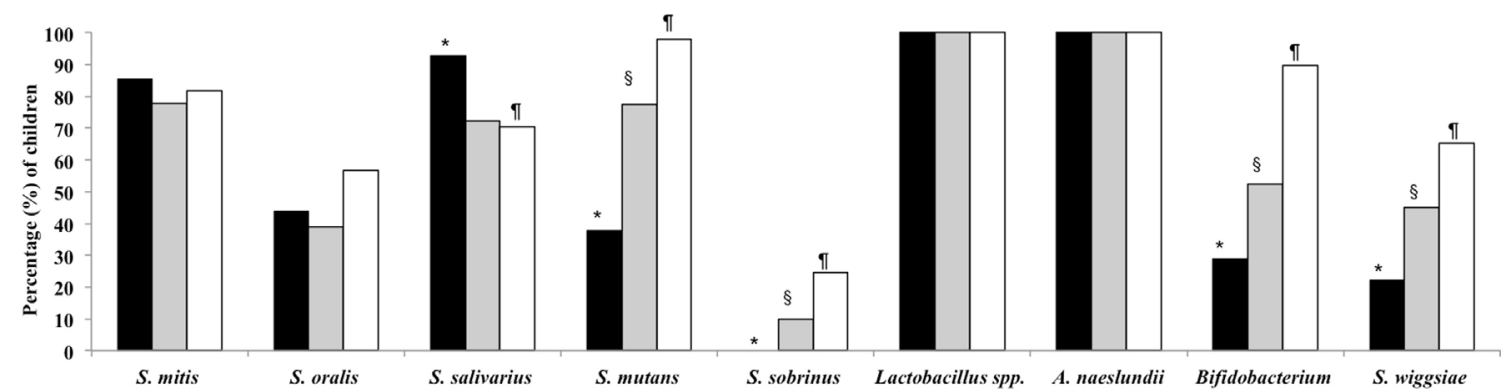

Caries status

- $\mathrm{CF} \quad \square \mathrm{ECC} \quad \square \mathrm{S}-\mathrm{ECC}$

Fig. 1. Percentage (\%) of children harboring the tested bacteria by qPCR.

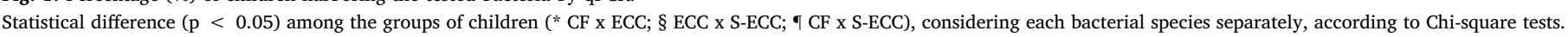
$\mathrm{CF}$ - caries-free, ECC - early childhood caries, S-ECC - severe-early childhood caries. 
Table 5

Microorganism levels [Means (medians) \pm standard errors] obtained by qPCR (ng/ $\mu \mathrm{L})$.

\begin{tabular}{|c|c|c|c|}
\hline & CF & ECC & S-ECC \\
\hline S. mitis & $0.028(0.008) \pm 0.007$ & $0.025(0.005) \pm 0.006$ & $0.036(0.006) \pm 0.012$ \\
\hline S. oralis & $0.040(0.000) \pm 0.015$ & $0.294(0.000) \pm 0.264$ & $0.012(0.006) \pm 0.002$ \\
\hline S. salivarius & $0.189(0.080) \pm 0.049^{*}$ & $0.041(0.008) \pm 0.011$ & $0.040(0.004) \pm 0.009^{\top}$ \\
\hline S. mutans & $1.661(0.011) \pm 0.075^{*}$ & $10.257(1.486) \pm 3.564^{\S}$ & $79.036(7.450) \pm 27.367^{\uparrow}$ \\
\hline S. sobrinus & $0.000(0.000) \pm 0.000$ & $0.030(0.000) \pm 0.018^{\S}$ & $0.489(0.000) \pm 0.328^{\top}$ \\
\hline Lactobacillus spp. & $75.210(58.490) \pm 10.540$ & $80.709(31.450) \pm 19.170$ & $88.742(63.370) \pm 14.174$ \\
\hline A. naeslundii & $10.427(7.857) \pm 2.606$ & $6.648(4.402) 1.154$ & $10.387(6.116) \pm 1.597$ \\
\hline Bifidobacterium spp. & $0.167(0.000) \pm 0.024$ & $0.298(0.002) \pm 0.117^{\S}$ & $2.316(0.621) \pm 0.502$ \\
\hline Scardovia wiggsiae & $0.072(0.000) \pm 0.058$ & $0.052(0.000) \pm 0.026^{\S}$ & $1.952(0.175) \pm 0.514^{\top}$ \\
\hline
\end{tabular}

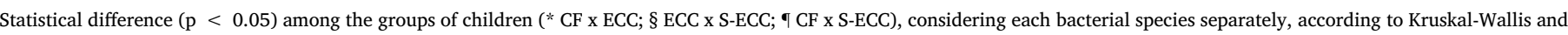
Mann-Whitney $U$ tests.

CF - caries-free, ECC - early childhood caries, S-ECC - severe-early childhood caries.

mutans and S. sobrinus remain important in this disease. This study showed that the detection of $S$. mutans and $S$. sobrinus was increased in children with more dental caries. This is consistent with another report in which children presenting $S$. mutans and $S$. sobrinus had higher caries scores (dmft) than children who presented with $S$. mutans but not $S$. sobrinus, and further the prevalence and levels of $S$. mutans and $S$. sobrinus were significantly higher in S-ECC children compared with CF children (Zhou et al., 2011).

An interesting finding of this present study was the inverse relationship between the levels of $S$. mutans or Bifidobacterium spp. and $S$. salivarius. A previous study (Corby et al., 2005) reported that the most abundant bacterial species in biofilms of children with dental caries were Actinomyces spp., S. mutans and Lactobacillus spp., whereas $S$. salivarius, $S$. mitis and $S$. oralis were predominant in $\mathrm{CF}$ children. However, $S$. salivarius seems not to be the predominant bacterial species detected in caries-free children. Comparing the microbial profile of 118 plaque samples collected from caries-active children with 330 from caries-free children, using reverse captured checkerboard method, 54 children had positive samples for $S$. salivarius and 83 children for $S$. sanguinis in caries-active group and 85 children were positive for $S$. salivarius and 118 for $S$. sanguinis in caries-free group (Corby et al., 2005). Our results also corroborated with this study in relation to inverse relationship between $S$. mutans and $S$. salivarius. The site of collection is determining for analysis of oral cavity microbiota. In the present study, saliva was chosen as the first screen of the differences between different groups of patients, before observing the microbiota of plaque and dentine carious lesions. The importance of site collection for oral microbiota analysis was highlighted in a previous study (Corby et al., 2005). A. naeslundii was increased in caries group only when the samples were collected from carious sites. When comparing biofilms of intact enamel surfaces from caries-active children with biofilm from caries-free children, no difference was observed in A. naeslundii detection (Corby et al., 2005). Similarly, our study shows no difference in $A$. naeslundii presence in saliva of children among the studied groups.

Early childhood caries is a multifactorial disease. Besides cariogenic oral microorganisms, socioeconomic-cultural factors contribute to increase the caries risk (Selwitz et al., 2007). The literature shows that children from low-income families (Corrêa-Faria, Martins-Júnior, Vieira-Andrade, Marques, \& Ramos-Jorge, 2013; Oliveira, Sheiham, \& Bönecker, 2008) or with mothers that had received less than 8 years of education (Oliveira et al., 2008) had higher prevalence of dental caries. In the current study, the severity of dental caries was associated with lower family income but no significant difference in maternal education was found between groups. Another strong risk factor for ECC is the high consumption of sweet snacks (Kalsbeek \& Verrips, 1994; Parisotto et al., 2010). The results from the dietary survey in the present study did not find significant differences in sugar intake among the groups. Rather, our results corroborated with those found in other studies that demonstrated that caries experience was not correlated with sugar exposure (Milgrom et al., 2000; Neves et al., 2015; Ohlund et al., 2007). It is important to recognize that some parents may minimize reporting the consumption of sugar in the diets of their children when completing questionnaires. Dietary data may also reflect current eating habits and not those corresponding to the period when dental caries started. Increased caries was also not related to infant bottle-feeding as previously reported (Parisotto et al., 2010), instead the duration of breastfeeding was statistically higher in caries groups (more than 12 months in ECC and S-ECC groups). There was a lack of studies on children aged more than 12 months simultaneously assessing caries risk in breastfed or bottle-fed children and the evidence concerning infant feeding as a risk factor for dental caries is still inconsistent (Tham et al., 2015).

Several questions about the frequency and duration of oral hygiene habits were asked in the questionnaire; however, there was no difference found among groups except for the age of starting tooth brushing. A previous study reported that $90 \%$ of the mothers with children ages 0-12 months were unaware of the need for tooth brushing during their children's first year. The authors highlight the importance of providing preventive orientation to the mothers about early childhood caries, emphasizing the first dental visit before the first year of life (Azevedo, Romano, Dos Santos Ida, \& Cenci, 2014).

In this present study, we used the criteria to assess dental caries status from the AAPD (2014). Because of differences in the definition of SECC based on child age, this led to a large standard deviation of the mean of dmfs in S-ECC group $(18.02 \pm 15.62)$. For future studies it seems likely it would be better if caries status including analysis based on the number of cavitated teeth. This might have resulted in clearer microbial associations with disease. We conclude that in addition to $S$. mutans, Bifidobacterium species, Scardovia wiggsiae and S. sobrinus are associated with the severity of early childhood caries. Marked differences in the detection of these species between caries-free and ECC children, however, were not observed, suggesting that the monitored caries species could be associated principally with more advanced lesions into dentin.

\section{Declaration of interests}

The authors declare that they have no conflict of interest.

\section{Acknowledgments}

This study was supported by grants (2012/19235-5; 2013/12167-7) from theSão Paulo Research Foundation (FAPESP), São Paulo, SP, Brazil and Coordination for the Improvement of Higher Education Personnel (CAPES). 


\section{References}

Acs, G., Lodolini, G., Kaminsky, S., \& Cisneros, G. J. (1992). Effect of nursing caries on body weight in a pediatric population. Pediatric Dentistry, 14(5), 302-305.

Acs, G., Shulman, R., Ng, M. W., \& Chussid, S. (1999). The effect of dental rehabilitation on the body weight of children with early childhood caries. Pediatric Dentistry, 21(2), 109-113.

American Academy of Pediatric Dentistry (2014). Policy on early childhood caries (ECC): Classifications, consequences and preventive strategies. Oral Health Policies, 50-52.

Azevedo, M. S., Romano, A. R. Dos Santos Ida, S., \& Cenci, M. S. (2014). Knowledge and beliefs concerning early childhood caries from mothers of children ages 0-12 months. Pediatric Dentistry, 36(3), 95-99.

Becker, M. R., Paster, B. J., Leys, E. J., Moeschberger, M. L., Kenyon, S. G., Galvin, J. L., et al. (2002). Molecular analysis of bacterial species associated with childhood caries. Journal of Clinical Microbiology, 40(3), 1001-1009.

Berkowitz, R. J. (2003). Causes, treatment and prevention of early childhood caries: A microbiologic perspective. Journal Canadian of Dental Association, 69(5), 304-307.

Byun, R., Nadkarni, M. A., Chhour, K. L., Martin, F. E., Jacques, N. A., \& Hunter, N. (2004). Quantitative analysis of diverse Lactobacillus species present in advanced dental caries. Journal of Clinical Microbiology, 42(7), 3128-3136.

Choi, E. J., Lee, S. H., \& Kim, Y. J. (2009). Quantitative real-time polymerase chain reaction for Streptococcus mutans and Streptococcus sobrinus in dental plaque samples and its association with early childhood caries. International Journal of Paediatric Dentistry, 19(2), 141-147.

Colak, H., Dülgergil, C. T., Dalli, M., \& Hamidi, M. M. (2013). Early childhood caries update: A review of causes, diagnoses, and treatments. Journal of Natural Science, Biology and Medicine, 4(1), 29-38.

Corby, P. M., Lyons-Weiler, J., Bretz, W. A., Hart, T. C., Aas, J. A., Boumenna, T., et al. (2005). Microbial risk indicators of early childhood caries. Journal of Clinical Microbiology, 43(11), 5753-5759.

Corrêa-Faria, P., Martins-Júnior, P. A., Vieira-Andrade, R. G., Marques, L. S., \& RamosJorge, M. L. (2013). Factors associated with the development of early childhood caries among Brazilian preschoolers. Brazilian Oral Research, 27(4), 356-362.

Davies, G. N. (1998). Early childhood caries-a synopsis. Community Dentistry Oral Epidemiology, 26(Suppl. 1), 106-116.

Drury, T. F., Horowitz, A. M., Ismail, A. I., Maertens, M. P., Rozier, R. G., \& Selwitz, R. H. (1999). Diagnosing and reporting early childhood caries for research purposes. A report of a workshop sponsored by the National Institute of Dental and Craniofacial Research the Health Resources and Services Administration, and the Health Care Financing Administration. Journal of Public Health Dentistry, 59(3), 192-197.

Dye, B. A., Thronton-Evans, G., Li, X., \& Iafolla, T. J. (2015). Dental caries and sealant prevalence in children and adolescents in the United States, 2011-2012, vol. 191, National Center for Health Statistics (NCHS) Data Brief, Centers for Disease Control and Prevention1-8. https://www.cdc.gov/nchs/data/databriefs/db191.pdf.

Jiang, W., Ling, Z., Lin, X., Chen, Y., Zhang, J., Yu, J., et al. (2014). Pyrosequencing analysis of oral microbiota shifting in various caries states in childhood. Microbial Ecology, 67(4), 962-969.

Kalsbeek, H., \& Verrips, G. H. (1994). Consumption of sweet snacks and caries experience of primary school children. Caries Research, 28(6), 477-483.

Kanasi, E., Dewhirst, F. E., Chalmers, N. I., Kent, R., Moore, A., Hughes, C. V., et al. (2010). Clonal analysis of the microbiota of severe early childhood caries. Caries Research, 44(5), 485-497.

Kolenbrander, P. E. (2000). Oral microbial communities: Biofilms, interactions, and genetic systems. Annual Reviews in Microbiology, 54, 413-437.

Kouidhi, B., Fdhila, K., Ben Slama, R., Mahdouani, K., Hentati, H., Najjari, F., et al. (2014). Molecular detection of bacteria associated to dental caries in 4-12-year-old Tunisian children. Microbial Pathogenesis, 71-72, 32-36.

Loesche, W. J. (1986). Role of Streptococcus mutans in human dental decay. Microbiology Reviews, 50(4), 353-380.

Low, W., Tan, S., \& Schwartz, S. (1999). The effect of severe caries on the quality of life in young children. Pediatric Dentistry, 21(6), 325-326.
Matsuki, T., Watanabe, K., Fujimoto, J., Kado, Y., Takada, T., Matsumoto, K, et al. (2004). Quantitative PCR with 16S rRNA-gene-targeted species-specific primers for analysis of human intestinal bifidobacteria. Applied of Environmental Microbiology, 70(1), 167-173.

Milgrom, P., Riedy, C. A., Weinstein, P., Tanner, A. C., Manibusan, L., \& Bruss, J. (2000). Dental caries and its relationship to bacterial infection, hypoplasia, diet, and oral hygiene in 6- to 36-month-old children. Community Dental Oral Epidemiology, 28(4), 295-306.

Neves, A. B., Lobo, L. A., Pinto, K. C., Pires, E. S., Requejo, M. E. P., \& Maia Antonio, L. C. A. G. (2015). Comparison between clinical aspects and salivary microbial profile of children with and without early childhood caries: A preliminary study. Journal of Clinical Pediatric Dentistry, 39(3), 209-214.

Ohlund, I., Holgerson, P. L., Backman, B., Lind, T., Hernell, O., \& Johansson, I. (2007). Diet intake and caries prevalence in four-year-old children living in a low-prevalence country. Caries Research, 41(1), 26-33.

Oliveira, L. B., Sheiham, A., \& Bönecker, M. (2008). Exploring the association of dental caries with social factors and nutritional status in Brazilian preschool children. European Journal of Oral Science, 116(1), 37-43.

Palmer, C. A., Kent, R., Loo, C. Y., Hughes, C. V., Stutius, E., Pradhan, N., et al. (2010). Diet and caries-associated bacteria in severe early childhood caries. Journal of Dental Research, 89(11), 1224-1229.

Parisotto, T. M., Steiner-Oliveira, C., Duque, C., Peres, R. C., Rodrigues, L. K., \& Nobredos-Santos, M. (2010). Relationship among microbiological composition and presence of dental plaque, sugar exposure, social factors and different stages of early childhood caries. Archives of Oral Biology, 55(5), 365-373.

Park, H. K., Lee, H. J., Jeong, E. G., Shin, H. S., \& Kim, W. (2010). The rgg gene is a specific marker for Streptococcus oralis. Journal of Dental Research, 89(11), 1299-1303.

Peterson, S. N., Snesrud, E., Schork, N. J., \& Bretz, W. A. (2011). Dental caries pathogenicity: A genomic and metagenomic perspective. International Dental Journal, 61(Suppl 1), 11-22.

SB Brasil (2010). Brazilian. Oral health. Report Available at: http://dab.saude.gov.br/ CNSB/sbbrasil/arquivos/projeto_sb2010_relatorio_final.pdf [Published: 30th Dec. 2016].

Sardi, J. C., Duque, C., Camargo, G. A., Hofling, J. F., \& Gonçalves, R. B. (2011) Periodontal conditions and prevalence of putative periodontopathogens and Candida spp. in insulin-dependent type 2 diabetic and non-diabetic patients with chronic periodontitis-A pilot study. Archives of Oral Biology, 56(10), 1098-1105.

Selwitz, R. H., Ismail, A. I., \& Pitts, N. B. (2007). Dental caries. Lancet, 369(9555), 51-59.

Tanner, A. C., Kent, R. L., Holgerson, P. L., Hughes, C. V., Loo, C. Y., Kanasi, E., et al. (2011). Microbiota of severe early childhood caries before and after therapy. Journal of Dental Research, 90(11), 1298-1305.

Tanner, A. C., Mathney, J. M., Kent, R. L., Chalmers, N. I., Hughes, C. V., Loo, C. Y., et al. (2011). Cultivable anaerobic microbiota of severe early childhood caries. Journal of Clinical Microbiology, 49(4), 1464-1474.

Tham, R., Bowatte, G., Dharmage, S. C., Tan, D. J., Lau, M. X., Dai, X., et al. (2015). Breastfeeding and the risk of dental caries: A systematic review and meta-analysis. Acta Paediatric, 104(467), 62-84.

van Houte, J., Lopman, J., \& Kent, R. (1996). The final pH of bacteria comprising the predominant flora on sound and carious human root and enamel surfaces. Journal of Dental Research, 75(4), 1008-1014.

Vadiakas, G. (2008). Case definition, aetiology and risk assessment of early childhood caries (ECC): A revisited review. European Archives of Paediatric Dentistry, 9(3), $114-125$.

Xiao, J., Klein, M. I., Falsetta, M. L., Lu, B., Delahunty, C. M., Yates, J. R., et al. (2012). The exopolysaccharide matrix modulates the interaction between 3D architecture and virulence of a mixed-species oral biofilm. PLoS Pathogens, 8(4), e1002623.

Zhou, Q., Qin, X., Qin, M., \& Ge, L. (2011). Genotypic diversity of Streptococcus mutans and Streptococcus sobrinus in 3-4-year-old children with severe caries or without caries. International Journal of Paediatric Dentistry, 21(6), 422-431. 